\title{
Assessing agri-environmental schemes for semi-natural grasslands during a 5-year period: can we see positive effects for vascular plants and pollinators?
}

\author{
Åke Berg ${ }^{1}$ (D) Erik Cronvall ${ }^{2}$. Åsa Eriksson ${ }^{2} \cdot$ Anders Glimskär $^{3} \cdot$ Matthew Hiron $^{3}$. \\ Jonas Knape $^{3} \cdot$ Tomas Pärt $^{3} \cdot$ Jörgen Wissman ${ }^{1} \cdot$ Michal Żmihorski $^{3,4} \cdot$ Erik Öckinger $^{3}$
}

Received: 30 October 2018 / Revised: 3 October 2019 / Accepted: 9 October 2019 /

Published online: 16 October 2019

(c) The Author(s) 2019

\begin{abstract}
An important function of agri-environmental schemes (AES) is to change management of pastures to better conserve biodiversity. However, the effects of most AES on biodiversity are poorly understood, especially when it comes to effects of AES management over time. The main aim of this study is to investigate if the species richness and abundance of grassland specialists of vascular plants and two important insect pollinator groups (bumblebees and butterflies) differ over time (5 years) in pastures with AES management (two value levels; general values and special values) and pastures without AES management. We also investigate if local vegetation characteristics and landscape composition relate to species richness in semi-natural grasslands. Using data from more than 400 sites we found that species richness of vascular plants (grassland specialists) was higher in pastures with AES management (for special and general values) compared to those without AES, which implies that these schemes do have value of the conservation of plant diversity. However, species richness and abundance of butterflies (grassland specialists) and bumblebees (all species) did not differ significantly among the three AES categories. We found no evidence that the type of AES management caused any changes in species richness of plants, butterflies or bumblebees during the 5 year period of our investigation. It appears that AES management that encourages uniform and minimum levels of grazing can have both positive and negative effects on biodiversity. For example, pollinators may benefit from a lower grazing intensity that could increase flower richness and heterogeneity in vegetation height. However, low grazing intensity may lead to increased cover of trees and shrubs, which can have negative effects for both insect pollinators and vascular plants. The effects of landscape composition were weak and only species richness of bumble bees were associated with landscape composition. Designing management regimes to maintain suitably heterogeneous vegetation layer, and continued long-term monitoring of biodiversity will be critical for safeguarding culturally and functionally important semi-natural grasslands.
\end{abstract}

Keywords AES $\cdot$ Management $\cdot$ Vegetation height $\cdot$ Flower richness $\cdot$ Tree cover $\cdot$ Shrub cover

Communicated by Dirk Sven Schmeller.

Extended author information available on the last page of the article 


\section{Introduction}

Temperate semi-natural grasslands are considered important for biodiversity conservation (Pärtel and Zobel 1999; Pärt and Söderström 1999; Öckinger et al. 2006; Wilson et al. 2012), but their deterioration in area in many parts of Western Europe has caused strong negative impacts on many species (Stoate et al. 2001, 2009; Dahlström et al. 2006; Dengler et al. 2014; Cousins et al. 2015). Therefore, semi-natural grasslands are prioritized for conservation and agri- environmental schemes (AES, i.e. subsidies for management of semi-natural grasslands). These schemes are designed and implemented in order to create suitable conditions for the conservation of organisms that are dependent on grazing or cutting and low chemical inputs in semi-natural grasslands (Wissman et al. 2013; Caruso et al. 2015; Żmihorski et al. 2016; Jakobsson and Lindborg 2015, 2017). Some studies have shown that AES management is linked to species rich habitats, because the schemes either promote biodiversity or target known biodiverse areas in farmland (e.g. Hiron et al. 2013a, b; Marja et al. 2014; Batary et al. 2015). However, evidence also shows that many agri-environment schemes have failed to protect biodiversity (Kleijn et al. 2001; Kleijn and Sutherland 2003; Konvicka et al. 2008; Breeuwer et al. 2009). In addition, the efficiency of AES to protect diversity seems to be strongly dependent on the composition of the surrounding landscape (Dallimer et al. 2010; Batary et al. 2015; Pe'er et al. 2014). Despite the recent increase in studies investigating AES management, many are snapshot studies comparing sites with and without AES management in small geographic areas within a single year (e.g. Hiron et al. 2013a, b; Caruso et al. 2015). This makes it difficult to conclude if AES management have actually enhanced biodiversity. There is a great need for large-scale studies where changes over time can be measured in sites with and without AES management, and also with different types of AES management. Such comparisons will help us evaluate the long-term effects of management subsidies.

To be part of AES, farmers have to agree to follow the guidelines relating to grazing management in semi-natural pastures. These guidelines prescribe minimum levels of grazing intensity in order to achieve relatively short vegetation, stop accumulation of litter and encroachment of shrubs. However, several studies have questioned the uniform management guidelines for grazing pressure and restrictions concerning tree/shrub cover in seminatural grasslands, as this can lead to too short vegetation with few flowering plants and lack of habitat heterogeneity for other organisms (Steffan-Dewenter and Leschke 2003; Sjödin et al. 2008; Jakobsson and Lindborg 2015, 2017). Vascular plants have traditionally been the main focus when setting criteria for conservation and AES management in semi-natural grasslands (Jakobsson and Lindborg 2015; Tälle et al. 2016). However, habitat requirements, and therefore effects of management, differ largely between different taxa (Vessby et al. 2002; Caruso et al. 2015). Thus, additional taxa other than vascular plants should also be considered when evaluating effects of AES management, especially in light of multi-national endeavours to highlight nature's benefits to people through ecosystem services such as pollination (IPBES 2016). For instance, flower-visiting insects like bumblebees and butterflies are important pollinators in agricultural landscapes, and flower rich semi-natural habitats may be critical habitat for many of these species (van Klink et al. 2015; Milberg et al. 2016). Earlier studies have shown that a certain amount of tall vegetation (often with a high flower-richness) is important for many pollinator species (Sjödin et al. 2008; Berg et al. 2011, 2013; Milberg et al. 2016). However, the less intensive management required to maintain patches of tall vegetation are in many cases not consistent with the requirements for receiving AES subsidies for pasture management (Bruppacher 
et al. 2016). In addition, previous research has suggested that the landscape surrounding areas targeted for conservation management could influence outcomes for biodiversity (Pärt and Söderström 1999; Söderström et al. 2001; Öckinger et al. 2012).Therefore, it is essential to consider landscape composition when both designing and evaluating efficiency of AES management on biodiversity.

The overall aim with the present study was to determine whether species richness and abundance of vascular plants, bumblebees and butterflies differ between pastures without AES management and those with AES management (split into two groups; pastures with AES for general values and AES for special values). The management of the pastures with AES aim at promoting grasslands specialists and not a high overall species richness (including forest species and species associated with other habitats). We therefore used a sub-set of grasslands specialists for vascular plants and butterflies. However, it was not possible to classify bumblebees as being specialists or not, so we used all species in the models for bumblebees. We also investigated if temporal and landscape factors influence relationships between AES management and biodiversity in semi-natural grasslands. Using data from a national monitoring program we analysed differences in species richness and abundance between (1) three categories of AES management, (2) two periods (2006-2010) and (2011-2015) and (3) dominant landscape composition i.e. arable dominated landscapes, forest landscapes with marginal agriculture or mosaic landscapes with forest, pastures and arable land (Glimskär et al. 2016). We interrogated the first two questions at the local scale (alpha diversity) as well as the landscape scale (gamma diversity), since species composition (and total species-richness) could differ between AES types. In addition, we analysed whether cover of trees and shrubs, ground vegetation height and flower richness differed among the three AES categories over time, since these factors have been shown to be important for bumblebees and butterflies, and the cover of trees and shrubs and vegetation height are used in the management prescriptions for semi-natural grasslands. An improved understanding of grassland diversity response to AES management, over time and in different landscape context, will help streamline AES guidelines for better conservation in agricultural landscapes.

\section{Methods}

\section{Long-term national monitoring program for grasslands}

The national Swedish program "Monitoring of semi-natural pastures and meadows" monitors vascular plants, bumblebees and butterflies. It started as an extension of the more general monitoring program National Inventory of Landscapes in Sweden, NILS (Ståhl et al. 2011).

The aim of the program was to introduce long-term monitoring of semi-natural grasslands with conservation values that were identified in a national inventory of grasslands (Jordbruksverket 2005). The collection of biodiversity data from 696 such semi-natural grasslands, situated within NILS landscape plots, was initiated in 2006. For our study we selected a sub-set $(n=408)$ of the semi-natural grasslands included in the monitoring program. We only included grassland categories with a sample size of $>20$ pastures. We excluded pastures in the north of Sweden because none of the sampled sites were included in AES. We also excluded rare and special types of pastures (e.g. AES for forest grazing, AES for mowing and AES for grazing alvar grasslands) due to the low numbers of 
such sites in the dataset, and due to lack of corresponding control sites without AES. All selected sites (see Fig. 1) were visited 1 year (several visits that year) during each of the two time periods (2006-2010 and 2011-2015). Thus, sites visited in 2006 were also visited in 5 years later in 2011, and sites visited in 2007 were visited a second time in 2012, etc.

\section{Field investigations}

\section{Vascular plants}

Within each pasture, occurrence of "indicator" vascular plant species that were considered management-favoured (Table 3 in Appendix) was recorded within nine circular sub- plots ( $0.28 \mathrm{~m}$ radius) situated within larger circular plots with a $10 \mathrm{~m}$ radius (range $=1-11$ large plots per pasture). This was mainly done during the period 15 June-15 August, depending on location and weather that year. The number of large plots within each pastures was proportional to the square root of the area of each pasture, i.e. one large circular plot for every 2 ha of pasture (Sjödin 2014). The cumulative number of "indicator" plant species found in the nine small plots within all $10 \mathrm{~m}$ radius plots in each pasture was the measure of species

Fig. 1 Study area and selected sampling sites $(\mathrm{n}=408)$ in southern Sweden. Sites were randomly selected within the monitoring program National Inventory of Landscapes in Sweden, which uses a systematic sample of grid squares covering the whole of Sweden

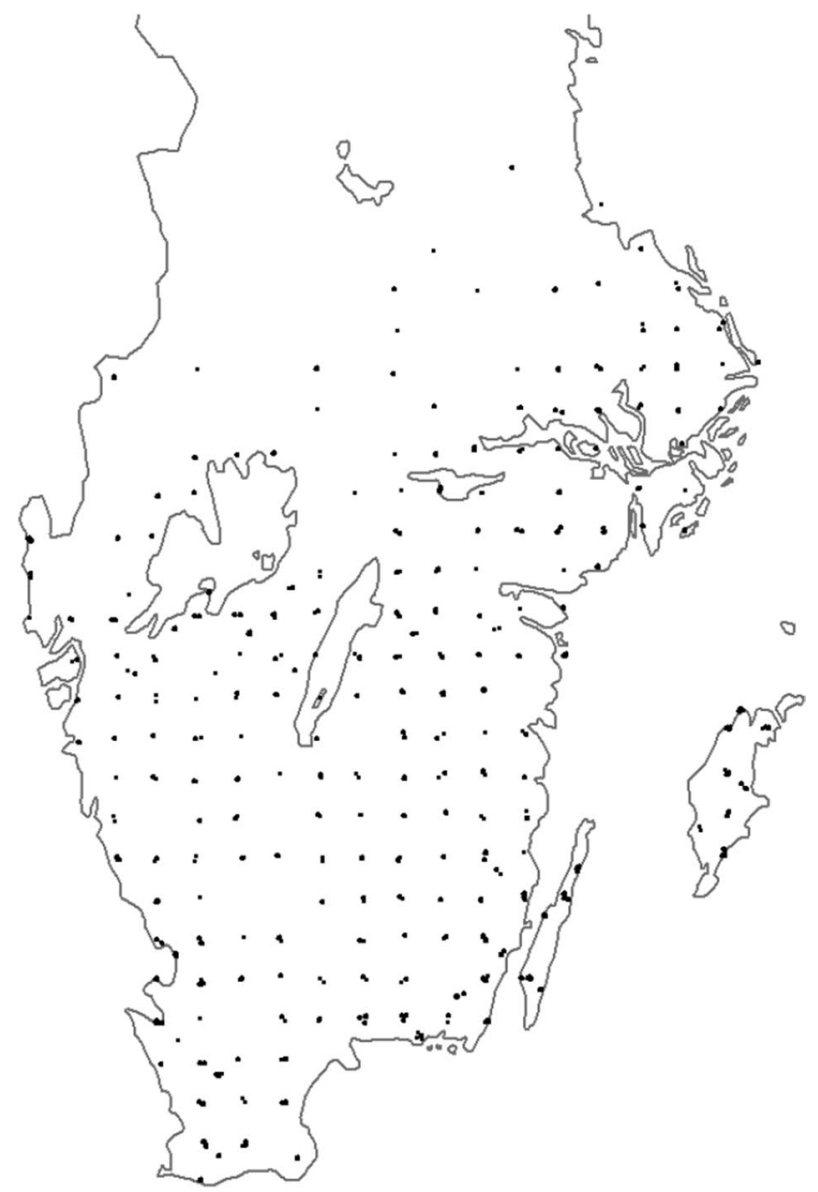


richness used as the dependent variable in statistical analyses. The cumulative number of occurrences of each "indicator" plant species found in the nine sub-plots within all $10 \mathrm{~m}$ radius plots in each pasture was the measure of "indicator" plant species abundance.

\section{Butterflies and bumblebees}

Butterflies and bumblebees were surveyed in the same pastures as plants, but transects were independent of the layout of plots used for sampling plants. The inventories were conducted by walking along predefined transects (divided into several segments per site) in the selected pastures (Cronvall 2017). The length and number of transects vary between sites, adjusting for shape of the grassland and aiming for a total transect length proportional to the size of the area (mean \pm S.D transect length $=1278 \pm 794 \mathrm{~m}$ ). All individuals observed within $5 \mathrm{~m}$ (butterflies) or $2 \mathrm{~m}$ (bumblebees) in front and to each side of the observer were recorded. If required, insects were captured for identification (Cronvall 2017). All sites were visited three times during one summer per site and period for butterflies and once per site and period (during the second or third butterfly visit) for bumblebees (Cronvall 2017). The three visits started close to 15 May, 1 July and 16 July but depended on weather conditions in different years. Field surveys were done during daytime (9 AM to 4:30 PM) when weather conditions were suitable (over $17{ }^{\circ} \mathrm{C}$, sunny, wind less than $8 \mathrm{~m} / \mathrm{s}$; Wikström et al. 2009; Cronvall 2017). We selected a sub-set of monitored butterflies that are grassland specialists and associated with natural grasslands to be included in the analyses (Table 4 in Appendix). All recorded bumblebee species were included, since no habitat preference classification of bumblebees was available, possibly because most bumblebee species are not habitat specialists.

\section{Cover of trees and shrubs, vegetation height and flower richness}

During field visits for the vascular plant inventory, the total coverage of trees and shrubs was estimated to the nearest whole percent of the plot area (Sjödin 2014). The average vegetation height (cover of three height classes, see Table 2) and cover of insect-pollinated flowers (estimated in 10\%o classes along transects) were calculated from data collected during the butterfly and bumblebee inventories along transects (Cronvall 2017).

\section{Collection of AES data}

Data from the Swedish Board of Agriculture about payments for AES subsidies for the period 2003-2013 were used to classify the pastures into the three management categories (1) No AES ( $\mathrm{n}=87$ and 94 in period 1 and period 2, respectively), (2) AES for general values ( $\mathrm{n}=78$ and 81 in period 1 and period 2, respectively), and (3) AES for special values $(n=225$ and 251 in period 1 and period 2, respectively). If sites were covered by more than one of the three management categories (hereafter AES type) they were classed according to the dominating AES type. The pastures eligible for subsidies (5-year agreements) are generally grasslands that have not been ploughed for at least 25 years (most of them not at all), have a natural vegetation suitable for feeding grazing animals (yearly grazing), and do not exceed specified levels of shrub and three cover. Sites designated as having special values should not have been affected by fertilizers and have high cultural or biological values (e.g. a typical grassland flora, often with red-listed species). These pasture have more detailed management prescriptions compared to those with more general values. AES data 
from 2014 and 2015 were not available at the time of analysis for this study. Therefore, we assume that the effects of AES management remain during this 2-year period, even if management of some sites could have changed during these 2 years.

\section{Statistical analyses}

We modelled local species richness and local abundance of butterflies, bumblebees and plants by using generalized additive mixed models (GAMM, six models in total) with quasi-Poisson (for richness) and negative-binomial (for abundance) error distributions and a log-link function in all cases. Each pasture $(n=408)$ was used as the sampling unit in all analyses and the species-richness or abundance values used are for the total transect length and plot areas in each pasture. In the GAMMs we used AES type (no AES, AES for general values and AES for high values), landscape type (arable dominated, forest dominated with arable fields, forest dominated with pastures) and period (first vs. second) as three explanatory variables. We also tested for two-way interactions between the three categorical variables but in all six GAMMs the interactions were insignificant and thus were excluded from the final models. In order to deal with the spatial dependence of the data, we included a spline interaction of the longitude and latitude. The year effect was included as random effect fitted with a ridge penalty spline (Wood 2017) to account for possible random variation among years. Sampling effort was also fitted with a spline as we expected nonlinear relationship between transect length (and number of plots) and species richness or abundance. All the GAMMs were performed in 'mgcv' package (Wood 2017) in R (R Core Team 2018).

We analysed overall species-richness (gamma diversity) among three AES types with the help of rarefaction curves (estimating total accumulated species richness). For this purpose, we draw curves of the expected cumulative number of species (with unconditioned 95\% confidence intervals) for a given number of randomly selected pastures for each AES type and period. Rarefaction curves were produced with the 'iNEXT' package (Hsieh et al. 2016) in R.

Finally, we analysed six vegetation characteristics (vegetation height split into three categories, flower richness, cover of trees and of shrubs) in relation to two explanatory variables: AES type and period, with permutation ANOVA with 1000 iterations, using lmPerm package (Wheeler and Torchiano 2016) in R. In these models, we initially considered interactions between the AES type and period, but as interactions were not statistically significant they were dropped and were not considered further.

\section{Results}

In total, we recorded 70 indicator plant species, 44 grassland specialist butterfly species (out of 97 recorded butterfly species) and 25 bumblebee species. The number of butterfly species per pasture (and year) ranged from 0 to 21 (on average 7.06 $\pm 3.89 \mathrm{SD}$ ) and the number of bumblebee species ranged from 0 to $13(2.86 \pm 2.08 \mathrm{SD})$ and plant species richness ranged from 0 to $24(6.49 \pm 5.00 \mathrm{SD})$. In the grassland butterfly community, the most widespread species were Aphantopus hyperantus $(\mathrm{n}=711$ occurrences; maximum number of occurrences $=2$ (years) $\times 408$ (pastures) $=816$ occurrences), Maniola jurtina $(\mathrm{n}=460)$ and Coenonympha pamphilus $(\mathrm{n}=431)$. In terms of abundance Aphantopus hyperantus was the most abundant butterfly $(\mathrm{n}=17,762$ individuals) followed by Maniola jurtina $(\mathrm{n}=7448)$ and Boloria selene 
$(\mathrm{n}=3600)$. The most commonly occurring bumblebee species were Bombus pascuorum $(\mathrm{n}=446$ occurrences and 2091 individuals), Bombus lucorum $(\mathrm{n}=338$ and $\mathrm{n}=2034)$ and Bombus terrestris $(\mathrm{n}=284$ and $\mathrm{n}=1165)$. The most commonly occurring indicator plants species were Plantago lanceolata $(n=431$ occurrences at pastures, $n=3405$ occurrences at subplots), Galium verum $(\mathrm{n}=387, \mathrm{n}=3970)$ and Pilosella officinarum $(\mathrm{n}=392, \mathrm{n}=2176)$.

\section{Effects of AES on local species richness of the three taxonomic groups (alpha level diversity)}

Species richness and abundance of vascular plants was positively linked with AES management. While pastures with AES (for general and special values) had similar richness, both types of AES management had higher species richness than sites without AES management. The vascular plant richness and abundance did not significantly differ among landscape types or the three AES categories among landscape types (Table 1, Fig. 2).

In contrast, the number of butterfly and bumblebee species as well as number of butterfly and bumblebee individuals did not differ between the three AES categories. The species richness and abundance of bumblebees was significantly higher in the two landscape types with higher levels of forest area (forested landscapes with marginal agriculture and mosaic landscapes with arable fields and pastures) compared to more arable dominated landscapes. There were no such effects of landscape type for local species richness and abundance of butterflies. We did not find any temporal differences in species richness and abundance of butterflies or bumblebees as there was no statistically significant effect of the period variable. Furthermore, the observed change between time periods for butterflies and bumblebees did not differ between AES categories or landscape types (Table 1, Fig. 2).

There were significant effects of longitude and latitude on the species richness and abundance of all three taxa (Table 1), indicating differences between regions. Furthermore, sampling effort (i.e. transect length or number of sample plots) was positively correlated with species richness and abundance of plants, butterflies and bumblebees. These factors were included in the models only to control for these design characteristics and avoid biases in model results and these patterns are not considered further.

\section{The effect of AES management on total accumulated species richness (gamma diversity)}

The rarefaction analyses of indicator vascular plants suggested that the overall species richness was clearly higher at sites with AES for special values than at sites without AES management for the first period. There was no significant difference in cumulative richness of vascular plants among AES categories for the second period, however 95\% confidence intervals only slightly overlapped between sites with special values and those without AES management (Fig. 3). The rarefaction analysis revealed no statistically significant differences in overall accumulated species richness of butterflies and bumblebees between the three AES categories (Fig. 3).

\section{The effect of pasture management on vegetation}

Five of the six analysed vegetation variables were significantly associated with AES category, but no variables showed statistically significant differences between the two time 


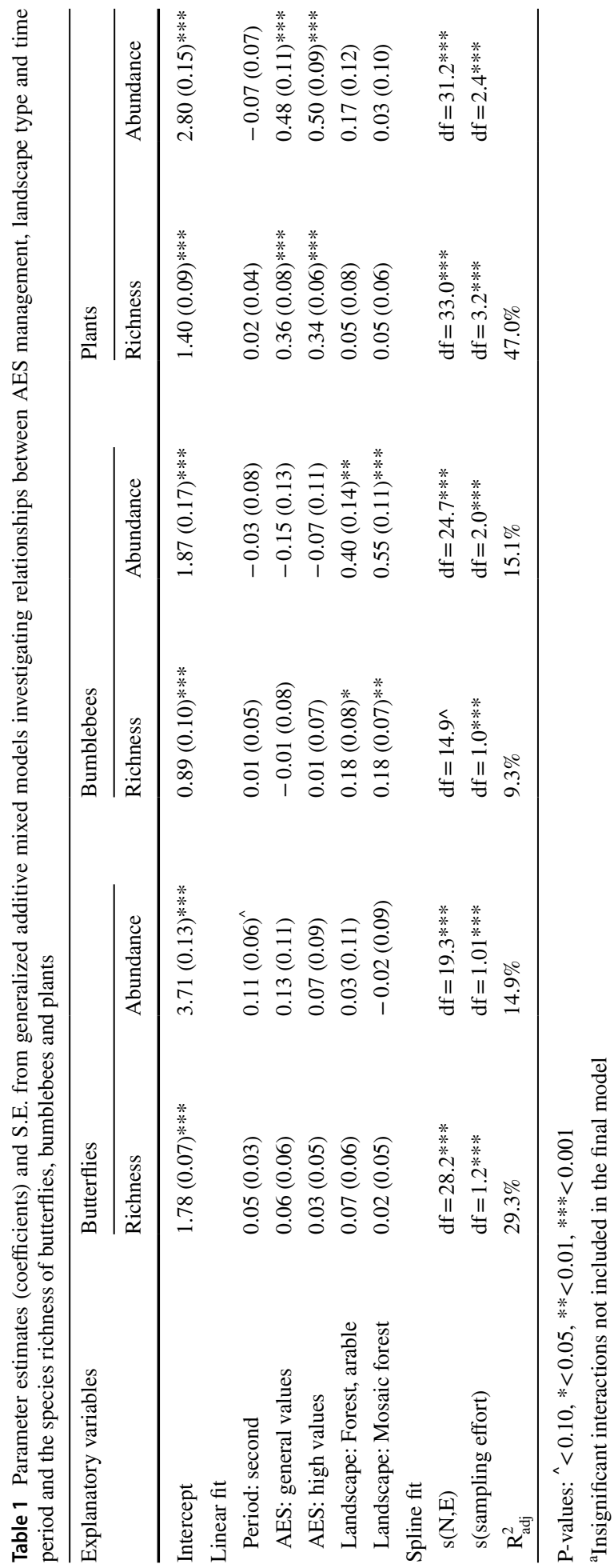



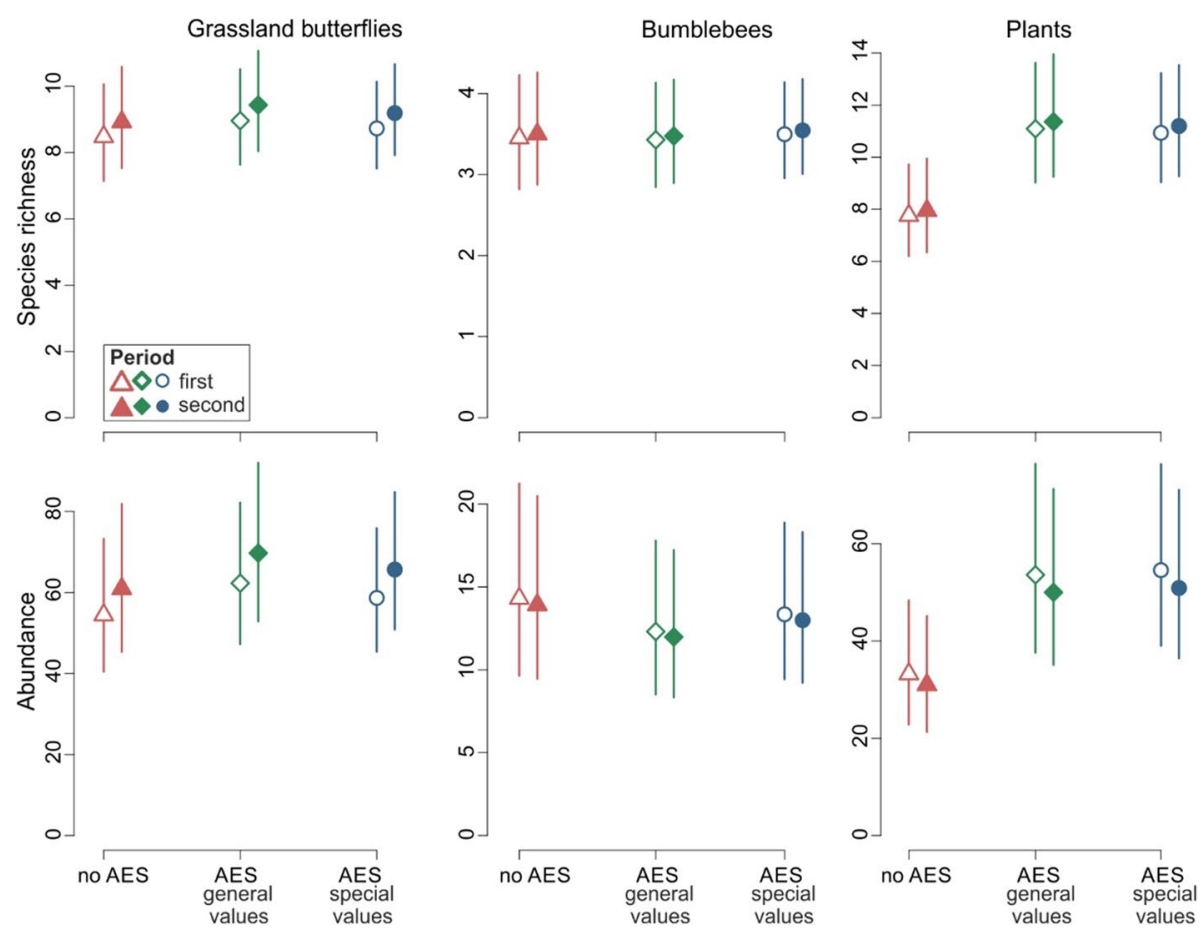

Fig. 2 Species richness of butterflies, bumblebees and plants (with 95\% CI) for the three AES categories during the two time periods as predicted by GAMMs 1-3 summarized in Table 1 . The predictions were done for averaged longitude, latitude, year and sampling effort measures

periods. Cover of short (i.e. $<5 \mathrm{~cm}$ tall) vegetation was higher at AES managed sites, while tall vegetation, shrubs and trees had higher cover at sites without AES management. Flower richness was lower at sites without AES management. No temporal changes in vegetation characteristics were associated with type of AES as no statistically significant interactions between AES type and period were recorded (Table 2).

\section{Discussion}

A major result from our study was that vascular plants had a higher species richness of grassland specialists in pastures with AES for special values and general values compared to sites without AES management, but there were no differences in species richness of butterflies and bumblebees between the three AES categories (Table 1, Fig. 2). The general trends were similar when gamma diversity was analysed, however, significant differences were restricted to the first time period (2006-2010) and only between sites with special values and sites without AES management. The positive association between AES management and plant richness probably reflects the fact that classification of pastures into having low, general or special values is often based on occurrence of a typical dry grassland flora (Jordbruksverket 2005). In addition, the AES management guidelines relating to grazing pressure, resulting in relatively low vegetation, are 

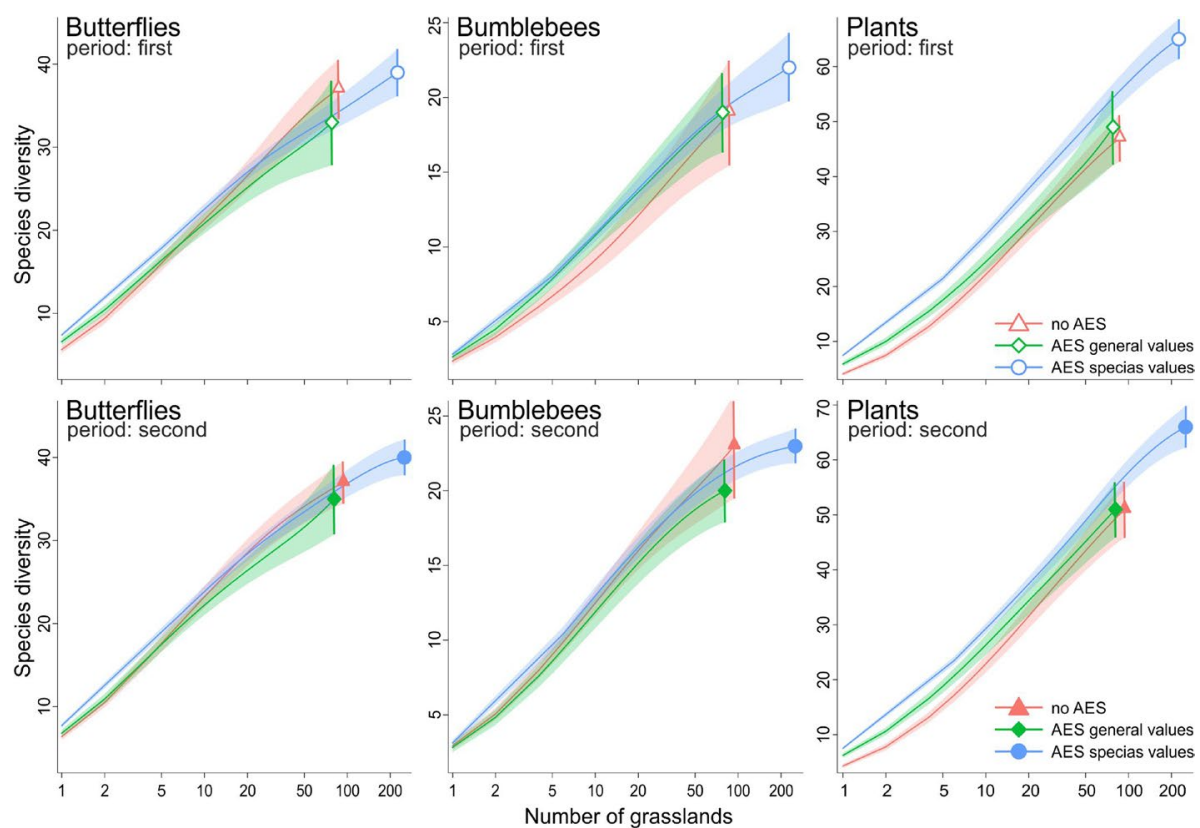

Fig. 3 Rarefaction curves and 95\% CI (transparent areas) showing expected cumulative number of butterfly, bumblebee and plant species as a function of the number of grasslands with different AES types (different colors) during the first (upper graphs) and second period (bottom graphs). Note that X-axes are log-transformed and y-axes are of different scales

Table 2 Mean $( \pm$ SD) values of vegetation characteristics on grassland under three types of AES during two time periods

\begin{tabular}{|c|c|c|c|c|c|c|c|c|}
\hline \multirow{2}{*}{$\begin{array}{l}\text { Management } \\
\text { Period }\end{array}$} & \multicolumn{2}{|c|}{ AES general values } & \multicolumn{2}{|c|}{ AES special values } & \multicolumn{2}{|l|}{ No AES } & \multicolumn{2}{|c|}{ Perm. ANOVA } \\
\hline & First & Second & First & Second & First & Second & Type & Period \\
\hline Veg. $<5 \mathrm{~cm}^{\mathrm{a}}$ & $29.2(23.5)$ & $26.5(21.8)$ & $30.1(24.8)$ & $27.8(21.4)$ & $20.9(22.1)$ & $19.5(21.5)$ & $<0.001$ & 0.084 \\
\hline Veg. $5-15 \mathrm{~cm}^{\mathrm{a}}$ & $33.8(15.3)$ & $30.3(17.7)$ & $33.7(19.5)$ & $33(19)$ & $32.5(18.5)$ & $31.1(21.3)$ & 1.0000 & 0.329 \\
\hline Veg. $>15 \mathrm{~cm}^{\mathrm{a}}$ & $34.8(25)$ & $40.4(24.5)$ & $32.5(24.2)$ & $36.7(23.3)$ & $40.9(28.5)$ & $40.1(26)$ & $<0.001$ & 0.089 \\
\hline Shrub cover & $7.9(11.5)$ & $7(10.4)$ & $5.7(7.2)$ & $5.8(7.2)$ & $12.7(17.8)$ & $14.6(20.1)$ & $<0.001$ & 0.231 \\
\hline Tree cover & 21.5 (18.6) & $20.1(17.1)$ & $17.8(17.1)$ & $16.5(16.2)$ & $36.1(26.4)$ & $35.8(25.6)$ & $<0.001$ & 0.293 \\
\hline $\begin{array}{l}\text { Flower } \\
\text { richness }^{\mathrm{a}}\end{array}$ & $1.2(1.7)$ & $2.2(2.5)$ & $1.6(2.9)$ & $1.9(2.7)$ & $0.8(1.1)$ & $1.6(2.6)$ & 0.048 & 0.252 \\
\hline
\end{tabular}

Results of permutation ANOVA (p-values for the effect of AES management and period) are given in last two columns

${ }^{a}$ Weighted by transect segment length, since estimates were made per transect

Significant $p$-values $(p<0.05)$ are shown in bold

often devised with plant diversity conservation in mind. Thus, many selected sites with AES management have suitable conditions for dry grassland plants because they are nutrient poor, dry sites with good light conditions (Grandin et al. 2013; Glimskär et al. 2018). In contrast, these factors may not necessarily benefit pollinators like butterflies and bumblebees (our study) or other taxa such as beetles, cryptogams and birds (Vessby et al. 2002; Caruso et al. 2015; Jakobsson and Lindborg 2017). 
A major ongoing threat to semi-natural grasslands is abandonment or too relaxed grazing pressure allowing for scrub encroachment, which negatively affects flora and fauna adapted to open habitats (Pykälä 2004; Pöyry et al. 2004). Therefore, we expected differences in pasture biodiversity between time periods that depended on AES management levels. However, our analyses did not reveal any changes in the species richness or abundance of the studied taxa (grassland specialists for vascular plants and butterflies) between the two time periods at sites with and without AES management (Table 1, Fig. 2). However, the time-span between the two inventory periods (5 years) might be too short to detect changes in species richness, especially for long-lived species (Lindborg and Eriksson 2004). Previous studies have suggested that changes in species richness could be time-lagged where species persist despite reductions in habitat quality caused by lack of management (Bommarco et al. 2014). Thus, continued monitoring over longer time periods will be essential in order to fully evaluate long-term effects of different AES management regimes, or lack thereof (see also Davey et al. 2010).

The lower cover of trees in pastures with AES management and the high species richness of vascular plants in these pastures (Table 2) suggests that the tree cover restrictions for eligibility to receive AES payments for pastures (i.e. not more than 50 trees/ha) were beneficial for the indicator plant species as they prefer dry, nutrient poor sites with good light conditions. We did not find the same patterns for relationships between tree cover and the species richness of butterflies and bumblebees. However, other studies have shown that species richness of butterflies and bumblebees are negatively associated with a high cover of trees (Pöyry et al. 2005; Glimskär et al. 2018), suggesting that the restrictions for tree cover in AES management might nonetheless be positive for all three organism groups we investigated. A possible explanation to the lack of a negative association between speciesrichness of butterflies and bumblebees and tree cover in our study is that AES sites with low tree cover also had lower vegetation height compared to sites without grazing (see below). Therefore, while AES management pastures are open (i.e. a positive effect of low tree cover) they also have short vegetation (i.e. negative effect due to lack of tall vegetation).

The quality of grassland habitats is often assessed by looking for plant species that indicate low nitrogen levels and lack of competition from tall vegetation. Our results are in line with expectations. However, the higher species richness of plants in sites with AES management compared to sites without AES management might be due to initial differences between sites with and without AES management. It is possible that the ongoing AES management, i.e. grazing have positive effects on species-richness and abundance of vascular plants typical for grazed pastures, but we could not detect such effects during the short 5-year period of the investigation. Maintaining grazing in semi-natural pastures to keep vegetation short and hinder succession is one of the main goals of grassland AES management. However, previous research has shown that the highest richness of vascular plants in semi-natural pastures is associated with intermediate cover of low vegetation and intermediate cover of shrubs (Glimskär et al. 2018). Furthermore, grazing obstacles (such as shrubs) can contribute to a higher abundance of flowering plants and a better plant reproduction (Pihlgren and Lennartsson 2007). We also found that pollinators (grassland specialists for butterflies and all species for bumblebees) did not show the same patterns as vascular plants across the management regimes we tested. A possible explanation for this is that the contrasting levels of tree cover (higher in sites without AES management), vegetation height (taller in sites without AES management) and flower richness (higher in AES management sites) level out species richness differences between the three AES categories through a mix of positive and negative habitat relationships.

Variation in vegetation height resulting from spatially heterogenous levels of grazing pressure and high flower richness have previously been shown to be associated with high 
species richness of pollinating and herbivorous insects (Pöyry et al. 2005, 2006; Sjödin et al. 2008; Berg et al. 2011: Milberg et al. 2016; Glimskär et al. 2018). The positive effect of tall vegetation has been suggested to be associated with a higher diversity of foraging resources (Southwood et al. 1979; Lawton 1983; Morris 2000). In addition, taller grass swards have multiple layers of vegetation and a larger structural variation, which might be important for shelter and foraging (Morris 2000; Reid and Hochuli 2007). Thus, too intensive management (such as whole season grazing with a high grazing pressure) will result in as short sward with few flowering plants unsuitable for pollinating insects. Management to benefit pollinators in pastures is complex, since neither intensive grazing nor lack of management during longer periods will benefit the nectar-feeding insects (Nilsson et al. 2013; Franzén and Nilsson 2008). However, alternative grazing regimes such as intermediate grazing pressure, late season grazing, or leaving small non-grazed areas, may create the heterogeneity needed to benefit multiple organism groups. These grazing regimes have previously been suggested as more favourable for biodiversity than the currently common management practice of whole-season grazing (Lennartsson et al. 2012; Wissman et al. 2008).

\section{Conclusion}

A large proportion $(\approx 50 \%)$ of the sites without AES were unmanaged so these sites will be overgrown with shrubs and trees in the long run. Thus, the AES system has an important positive effect on continuation of pasture management, although current management regimes are not optimal for all taxa. However, there may be a time lag in the effects of ceased (or changed) management on some species (e.g. some plants and insects) and the relatively "high" species richness at sites without AES management (Fig. 3) might be due to an extinction debt (Bommarco et al. 2014), i.e. the species will eventually go locally extinct in the long run if suitable management is not implemented. As a consequence, it is vital that monitoring of semi-natural pastures continues past the 5 years of data available for inclusion in this study if we are to evaluate longer term effects of AES management regimes.

Historically, the management of the pastures has been more variable compared to the present day (hay-cutting, different grazing regimes), see Dahlström et al. (2006). AES will have to encourage management regimes that create heterogeneity if the populations of ecosystem service providers such as pollinators are to reach or be maintained at a favourable conservation status in grasslands and the wider landscape. The long-term effects of the current management (whole season grazing) on grassland plants are unknown. Researchers, managers and farmers should collaborate to implement Before-After-Control-Impact Studies of different pasture management practices to disentangle cause and effects of different grazing regimes on biodiversity. This together with continued long-term monitoring could ensure better management for conservation of grassland plants and pollinating insects.

Acknowledgements Open access funding provided by Swedish University of Agricultural Sciences. The Swedish Board of Agriculture initiated program "Monitoring of semi-natural pastures and meadows" and finance the program since 2006. The Swedish Board of Agriculture also commissioned and financed a complementary project for analysing effects of AES based on these data.

Open Access This article is distributed under the terms of the Creative Commons Attribution 4.0 International License (http://creativecommons.org/licenses/by/4.0/), which permits unrestricted use, distribution, and reproduction in any medium, provided you give appropriate credit to the original author(s) and the source, provide a link to the Creative Commons license, and indicate if changes were made. 


\section{Appendix}

See Tables 3 and 4.

Table 3 Indicator species of vascular plants (Sjödin 2014)
Ophioglossum vulgatum

Botrychium lunaria

Luzula campestris

Luzula multiflora/L. pallescens/L. sudetica

Poa alpina

Briza media

Helictotrichon pratensis

Phleum alpinum

Danthonia decumbens

Nardus stricta

Carex panicea

Carex hostiana

Bistorta vivipara

Lychnis flos-cuculi

Dianthus deltoides

Pulsatilla vulgaris

Aconitum lycoctonum

Trollius europaeus

Cardamine pratensis

Parnassia palustris

Filipendula vulgaris

Alchemilla spp.

Trifolium fragiferum

Lotus corniculatus

Linum catharticum

Polygala spp.

Helianthemum spp.

Pimpinella saxifraga

Primula veris/P. elatior

Primula farinosa

Armeria maritima

Centaurium spp.

Gentiana pneumonanthe

Gentianella campestris

Galium verum

Ajuga pyramidalis

Thymus serpyllum

Veronica spicata

Veronica officinalis

Melampyrum pratense/M. sylvaticum

Euphrasia spp.

Bartsia alpina
Pedicularis palustris

Pedicularis sylvatica

Rhinanthus spp.

Pinguicula vulgaris

Plantago media

Plantago lanceolata

Succisa pratensis

Campanula rotundifolia

Antennaria dioica

Leucanthemum vulgare

Arnica montana

Carlina vulgaris

Serratula tinctoria

Saussurea alpina

Cirsium helenioides

Pilosella spp.

Hypochoeris maculata

Leontodon hispidus

Scorzonera humilis

Crepis praemorsa

Triglochin palustris

Triglochin maritima

Epipactis palustris

Platanthera spp.

Gymnadenia conopsea

Dactylorhiza incarnata

Dactylorhiza maculata

Orchis mascula 
Table 4 Butterfly species classified as grassland specialists $(n=46)$ that were included in the analyses of species richness (Glimskär et al. 2018)

\begin{tabular}{ll}
\hline Adscita statices & Lycaena phlaeas \\
Aphantopus hyperantus & Lycaena virgaureae \\
Argynnis aglaja & Maculinea arion \\
Argynnis niobe & Maniola jurtina \\
Argynnis paphia & Melitaea cinxia \\
Aricia agestis & Ochlodes sylvanus \\
Aricia artaxerxes & Ossoria lathonia \\
Aricia nicias & Parnassius apollo \\
Boloria euprosyne & Plebejus argus/idas \\
Boloria selene & Plebejus argyrognomon \\
Coenonumpha arcania & Polyommatus amandus \\
Coenonympha hero & Polyommatus dorylas \\
Coenonympha pamphilus & Polyommatus icarus \\
Cupido minimus & Polyommatus semiargus \\
Eumedonia eumedon & Pyrgus alveus \\
Glaucopsyche alexis & Pyrgus armoricanus \\
Hamearis lucina & Pyrgys malvae \\
Hemaris tityus & Thymelicys lineola \\
Hesperia comma & Zygaena filependulae \\
Hipparchia semele & Zygaena lonicerae \\
Lasiommata megera & Zygaena minos \\
Lycaena helle & Zygaena osterodensis \\
Lycaena hippothoe & \\
\hline & \\
& Zyciae \\
\hline
\end{tabular}

\section{References}

Batary P, Dicks LV, Kleijn D, Sutherland WJ (2015) The role of agri-environment schemes in conservation and environmental management. Conserv Biol 29:1006-1016

Berg ̊̊, Ahrné K, Öckinger E, Svensson R, Söderström B (2011) Butterfly distribution and abundance is affected by variation in the Swedish forest farmland landscape. Biol Conserv 144:2819-2831

Berg Å, Ahrné K, Öckinger E, Svensson R, Wissman J (2013) Butterflies in semi-natural pastures and power-line corridors-effects of flower-richness, management and structural vegetation characteristics. Insect Conserv Divers 6:639-657

Bommarco R, Lindborg R, Marini L, Öckinger E (2014) Extinction debt for plants and flower-visiting insects in landscapes with contrasting land use history. Divers Distrib 20:591-599

Breeuwer A, Berendse F, Willems F, Foppen R, Teunissen W, Schekkerman H, Goedhart P (2009) Do meadow birds profit from agri-environment schemes in Dutch agricultural landscapes? Biol Conserv 142:2949-2953

Bruppacher L, Pellet J, Arlettaz R, Humbert JY (2016) Simple modifications of mowing regime promote butterflies in extensively managed meadows: evidence from field-scale experiments. Biol Conserv 196:196-202

Caruso A, Öckinger E, Winqvist C, Ahnström J (2015) Different patterns in species richness and community composition between trees, plants and epiphytic lichens in semi-natural pastures under agri-environment schemes. Biodivers Conserv 24:1729-1742

Cousins SAO, Auffret AG, Lindgren J, Tränk L (2015) Regional-scale land-cover change during the 20th century and its consequences for biodiversity. Ambio 44(Suppl. 1):17-27

Cronvall E (2017) Fältinstruktion för fjärilar och humlor i ängs- och betesmarker. Institutionen för skoglig resurshållning (in Swedish) Sveriges Lantbruksuniversitet, Umeå. https://www.slu.se/globalassets/ew/ org/centrb/nils/publikationer/2017/faltinstruktion_fjaril_2017_webb.pdf. Accessed 3 July 2018 
Dahlström A, Cousins SAO, Eriksson O (2006) The history (1620-2003) of land use, people and livestock, and the relationship to present plant species diversity in a rural landscape in Sweden. Environ Hist 12:191-212

Dallimer M, Gaston K, Skinner AMJ, Hanley N, Acs S, Armsworth PR (2010) Field-level bird abundances are enhanced by landscape-scale agri-environment scheme uptake. Biol Lett 6:643-646

Davey CM, Vickery JA, Boatman N, Chamberlain DE, Patty HR, Siriwardena GM (2010) Assessing the impact of Entry Level Stewardship on lowland farmland birds in England. Ibis 152:459-474

Dengler J, Janisová M, Török P, Wellstein C (2014) Biodiversity of Palaearctic grasslands: a synthesis. Agric Ecosyst Environ 182:1-14

Franzén M, Nilsson SG (2008) How can we preserve and restore species richness of pollinating insects on agricultural land? Ecography 31:698-708

Glimskär A, Arlt D, Grandin U, Kindström M, Kindström S, Wikberg S, Gunnarsson U, Hedenbo P, Rygne H (2016) Resultat för småbiotoper, gräsmarker och myrar i regional miljöövervakning 2009-2014. Länsstyrelsen i Örebro län, Örebro. Publ. nr 2016:35

Glimskär A, Berg A, Żmihorski M, Cronvall E, och Eriksson $\AA$ (2018) Kvalitetsförändringar i ängs- och betesmarker med och utan miljöersättning. Utvärderingsrapport 2017:4. Jordbruksverket, Jönköping

Grandin U, Lenoir L, Glimskär A (2013) Are restricted species checklists or ant communities useful for assessing plant community composition and biodiversity in grazed pastures? Biodivers Conserv 22:1415-1434

Hiron M, Berg ̊̊, Eggers S, Pärt T (2013a) Are farmsteads over-looked biodiversity hot spots in intensive agricultural ecosystems? Biol Conserv 159:332-342

Hiron M, Berg Å, Eggers S, Josefsson J, Pärt T (2013b) Bird diversity relates to agri-environment schemes at local and landscape level in intensive farmland. Agr Ecosyst Environ 176:9-16

Hsieh TC, Ma KH, Chao A (2016) iNEXT: iNterpolation and EXTrapolation for species diversity. R package version 2.0.12. http://chao.stat.nthu.edu.tw/blog/software-download/

IPBES (2016) Summary for policymakers of the assessment report of the Intergovernmental SciencePolicy Platform on Biodiversity and Ecosystem Services on pollinators, pollination and food production. In: Potts SG, Imperatriz-Fonseca VL, Ngo HT, Biesmeijer JC, Breeze TD, Dicks LV, Garibaldi LA, Hill R, Settele J, Vanbergen AJ, Aizen MA, Cunningham SA, Eardley C, Freitas BM, Gallai N, Kevan PG, Kovács-Hostyánszki A, Kwapong PK, Li J, Li X, Martins DJ, Nates- Parra G, Pettis JS, Rader R, Viana BF (eds) Secretariat of the intergovernmental science-policy platform on biodiversity and ecosystem services, Bonn, Germany $36 \mathrm{p}$

Jakobsson S, Lindborg R (2015) Governing nature by numbers-EU subsidy regulations do not capture the unique values of woody pastures. Biol Conserv 191:1-9

Jakobsson S, Lindborg R (2017) The importance of trees for woody pasture bird diversity and effects of the EU tree density policy. J Appl Ecol 54:1638-1647

Jordbruksverket (2005) Ängs- och betesmarksinventeringen 2002-2004. Rapport 2005:1. Jönköping

Kleijn D, Sutherland WJ (2003) How effective are European agri-environment schemes in conserving and promoting biodiversity? J Appl Ecol 40:947-969

Kleijn D, Berendse F, Smit R, Gilissen N (2001) Agri-environment schemes do not effectively protect biodiversity in Dutch agricultural landscapes. Nature 413:723-725

Konvicka M, Benes J, Cizek O, Kopecek F, Konvicka O, Vitaz L (2008) How too much care kills species: Grassland reserves, agri-environmental schemes and extinction of Colias myrmidone (Lepidoptera: Pieridae) from its former stronghold. J Insect Conserv 12:519-525

Lawton JH (1983) Plant architecture and the diversity of phytophagous insects. Ann Rev Entomol 28:23-39

Lennartsson T, Wissman J, Bergström HM (2012) The effect of timing of grassland management on plant reproduction. J Ecol, Int. https://doi.org/10.1155/2012/156274

Lindborg R, Eriksson O (2004) Historical landscape connectivity affects present plant species diversity. Ecology 85:1840-1845

Marja R, Herzon I, Viik E, Elts J, Mänd M, Tscharntke T, Batáry P (2014) Environmentally friendly management as an intermediate strategy between organic and conventional agriculture to support biodiversity. Biol Conserv 178:146-154

Milberg P, Bergman KO, Cronvall E, Eriksson ÅI, Glimskär A, Islamovic A, Jonason D, Löfqvist Z, Westerberg L (2016) Flower abundance and vegetation height as predictors for nectar-feeding insect occurrence in Swedish semi-natural grasslands. Agric Ecosyst Environ 230:47-54

Morris MG (2000) The effects of structure and its dynamics on the ecology and conservation of arthropods in British grasslands. Biol Conserv 95:129-142

Nilsson SG, Franzén M, Pettersson LB (2013) Land-use changes, farm management and the decline of butterflies associated with semi-natural grasslands in southern Sweden. Nat Conserv 6:31-48 
Öckinger E, Eriksson AK, Smith HG (2006) Effects of grassland abandonment, restoration and management on butterflies and vascular plants. Biol Conserv 133:291-300

Öckinger E, Lindborg R, Sjödin NE, Bommarco R (2012) Landscape matrix modifies richness of plants and insects in grassland fragments. Ecography 35:259-267

Pärt T, Söderström B (1999) The effects of management regimes and location in landscape on the conservation of farmland birds breeding in semi-natural pastures. Biol Conserv 90:113-123

Pärtel M, Zobel M (1999) Small-scale plant species richness in calcareous grasslands determined by the species pool, community age and shoot density. Ecography 22:153-159

Pe'er G, Dicks LV, Visconti P, Arlettaz A, Baldi A, Benton TG, Collins S, Dieterich M, Gregory RD, Hartig F, Henle K, Hobson PR, Kleijn D, Neumann RK, Robijns T, Schmidt J, Shwartz A, Sutherland WJ, Turbé A, Wulf F, Scott AV (2014) EU agricultural reform fails on biodiversity. Extra steps by Member States are needed to protect farmed and grassland ecosystems. Science 344:1090-1092

Pihlgren A, Lennartsson T (2007) Floral resources in semi-natural grasslands-significance of grazing intensity and spatial variation. In: Pihlgren A (2007) Small scale structures and grazing intensity in semi-natural pastures - Effects on plants and insects. Doctoral Thesis no: 2007:13. Faculty of Natural Resources and Agricultural Sciences, Swedish University of Agricultural Sciences

Pöyry J, Lindgren S, Salminen J, Kuussaari M (2004) Responses of butterfly and moth species to restored cattle grazing in semi-natural grasslands. Biol Conserv 122:465-478

Pöyry J, Lindgren S, Salminen J, Kuussaari M (2005) Responses of butterfly and moth species to restored cattle grazing in semi-natural grasslands. Biol Conserv 122:465-478

Pöyry J, Luoto M, Paukkunen J, Pykälä J, Raatikainen K, Kuussaari M (2006) Different responses of plants and herbivore insects to a gradient of vegetation height: an indicator of the vertebrate grazing intensity and successional age. Oikos 115:401-412

Pykälä J (2004) Cattle grazing increases plant species richness of most species trait groups in mesic semi-natural grasslands. Plant Ecol 175:217-226

R Core Team (2018) R: A language and environment for statistical computing. R Foundation for Statistical Computing, Vienna, Austria https://www.R-project.org/

Reid AM, Hochuli DF (2007) Grassland invertebrate assemblages in managed landscapes: effect of host plant and microhabitat architecture. Austral Ecol 32:708-718

Sjödin M (2014) Fältinstruktion för nationell inventering av landskapet i Sverige. Institutionen för Skoglig resurshushållning, Sveriges Lantbruksuniversitet, 90183 Umeå

Sjödin NE, Bengtsson J, Ekbom B (2008) The influence of grazing intensity and landscape composition on the diversity and abundance of flower-visiting insects. J Appl Ecol 45:763-772

Söderström B, Svensson B, Vessby K, Glimskär A (2001) Plants, insects and birds in semi-natural pastures in relation to local habitat and landscape factors. Biodivers Conserv 10:1839-1863

Southwood TRE, Brown VK, Reader PM (1979) The relationships of plant and insect diversities in succession. Biol J Linn Soc 12:327-348

Ståhl G, Allard A, Esseen PA, Glimskär A, Ringvall A, Svensson J, Sundquist S, Christensen P, Gallegos Torell Å, Högström M, Lagerqvist K, Marklund L, Nilsson B, Inghe O (2011) National Inventory of Landscapes in Sweden (NILS) scope, design, and experiences from establishing a multiscale biodiversity monitoring system. Environ Monit Assess 173:579-595

Steffan-Dewenter I, Leschke K (2003) Effects of habitat management on vegetation and above-ground nesting bees and wasps of orchard meadows in Central Europe. Biodivers Conserv 12:1953-1968

Stoate C, Boatman ND, Borralho RJ, Carvalho CR, de Snoo GR, Eden P (2001) Ecological impacts of arable intensification in Europe. J Environ Manag 63:337-365

Stoate C, Baldi A, Beja P, Boatman ND, Herzon I, van Doorn S, de Snoo GR, Rakosy L, Ramwell C (2009) Ecological impacts of early 21 st century agricultural change in Europe - A review. J Environ Manag 91:22-46

Tälle M, Deák B, Poschlod P, Valkó O, Westerberg L, Milberg P (2016) Grazing vs mowing: a metaanalysis of biodiversity benefits for semi-natural grassland management. Agric Ecosyst Environ 222:200-212

van Klink R, van der Plas F, van Noordwijk CGE, Wallis de Vries MF, Olff H (2015) Effects of large herbivores on grassland arthropod diversity. Biol Rev 90:347-366

Vessby K, Söderström B, Glimskär A, Svensson B (2002) Species-richness correlations of six different taxa in Swedish seminatural grasslands. Conserv Biol 16:430-439

Wheeler B, Torchiano M (2016) lmPerm: permutation tests for linear models. R package version, 2.1.0. https://CRAN.R-project.org/package $=1 \mathrm{mPerm}$

Wikström L, Milberg P, Bergman KO (2009) Monitoring of butterflies in seminatural grasslands: diurnal variation and weather effects. J Insect Conserv 13:203-211 
Wilson JB, Peet RK, Dengler J, Pärtel M (2012) Plant species richness: the world records. J Veg Sci 23:796-802

Wissman J, Lennartsson T, Berg ^ (2008) Semi-natural grassland management and biodiversity in a northEuropean perspective: the reproduction and population structure of Primula veris L. (Primulaceae) an example of a management perspective. Grass1 Sci Eur 13:27-38

Wissman J, Berg А̊, Ahnström J, Wikström J, Hasund KP (2013) How can the Rural Development Programme's agri-environmental payments be improved? Experiences from other countries. Swed Board Agric Rep 2013:21

Wood SN (2017) Generalized additive models: an introduction with R, 2nd edn. Chapman and Hall/CRC, Boca Raton

Żmihorski M, Berg Å, Pärt T (2016) Forest clear-cuts as additional habitat for breeding farmland birds in crisis. Agric Ecosyst Environ 233:291-297

Publisher's Note Springer Nature remains neutral with regard to jurisdictional claims in published maps and institutional affiliations.

\section{Affiliations}

Åke Berg' ${ }^{1}$ - Erik Cronvall ${ }^{2}$. Åsa Eriksson ${ }^{2} \cdot$ Anders Glimskär $^{3} \cdot$ Matthew Hiron ${ }^{3}$. Jonas Knape ${ }^{3}$. Tomas Pärt ${ }^{3}$. Jörgen Wissman ${ }^{1} \cdot$ Michal Żmihorski $^{3,4} \cdot$ Erik Öckinger $^{3}$

\section{Åke Berg}

ake.berg@slu.se

1 Swedish Biodiversity Centre, Swedish University of Agricultural Sciences, Box 7016, 75007 Uppsala, Sweden

2 Department of Forest Resource Management, Swedish University of Agricultural Sciences, 90183 Umeå, Sweden

3 Department of Ecology, Swedish University of Agricultural Sciences, Box 7044, 75007 Uppsala, Sweden

4 Mammal Research Institute, Polish Academy of Sciences, Stoczek 1, 17-230 Białowieża, Poland 